\title{
A DIGITALIZÁCIÓ ÉS A MUNKAVÉGZÉSI FORMÁK
}

\section{DIGITISATION AND TYPES OF WORK}

\author{
Makó Csaba', Illéssy Miklós², Borbély András ${ }^{3}$ \\ 1 professor emeritus, Nemzeti Közszolgálati Egyetem \\ mako.csaba@tk.mta.hu \\ ${ }^{2}$ tudományos munkatárs, MTA Társadalomtudományi Kutatóközpont Szociológiai Intézet \\ illessy.miklos@tk.mta.hu \\ ${ }^{3}$ doktorandusz, Szent István Egyetem \\ andrasborbely1989@gmail.com
}

\section{ÖSSZEFOGLALÁS}

A tanulmány az automatizáció/robotizáció foglalkoztatásra és a munkavégzésre gyakorolt feltételezett hatásaival foglalkozik, a témában domináló két elméleti-módszertani megközelítés alapján. Az első megközelítés a „foglalkozásra”, a másik a munkavégzésre jellemző „feladatstruktúrára" koncentrál. Az alkalmazott megközelítések egymástól radikálisan eltérően prognosztizálják a digitalizáció eredményezte foglalkoztatási veszteségeket. A szerzők a második, az ún. feladatorientált megközelítésre alapozva a munkafeladatok kognitív tartalma alapján a következő munkatípusokat különböztetik meg: kreatív, ellenőrzött problémamegoldás és taylori - azaz a tömeggyártásra jellemző - munkavégzési formák. Az Európai munkakörülmények-felmérés (European Working Condition Survey - EWCS) különböző hullámainak $(2005,2010,2015)$ adatai alapján hazánkban csökkent a kreatív munkások aránya (2005 és 2015 között 44\%-ról 37\%-ra), miközben a rutin munkavégzést képviselő taylori munkát végzők aránya nőtt (2005 és 2015 között 27\%-ról 33\%-ra). Ez azt jelenti, hogy a 2008-as pénzügyi és gazdasági válságot követően Magyarországon figyelemre méltóan emelkedett a digitalizációnak leginkább kitett munkahelyek aránya.

\section{ABSTRACT}

The paper is focusing on the anticipated impacts of automation on employment and work, and two mainstream views of are presented. The first one is occupation-centred, the second one is the job-task focused approach. According to these approaches the anticipated impacts of digitisation/automation on employment are rather varied. The authors - using the job-task centred approach - distinguish between creative, constrained problem solvers and taylorized workers indicating the cognitive content and the level of autonomy employees enjoy at work. Comparing the European Working Condition Survey's various waves (2005, 2010 and 2015) it is necessary to indicate that in Hungary the share of creative workers decreased (from 44\% to 37\% between 2005 and 2015, while the share of taylorized workers increased (from 27\% to 33\% between 2005 and 2015). This means that the growing share of taylorized workers is at risk to lose their job under the impact of digitisation. 
Kulcsszavak: digitalizáció, automatizáció/robotizáció nyugtalanság, foglalkozás vs. feladatcentrikus megközelítés, kreatív, ellenőrzött problémamegoldó és taylori munkavállalók, Európai munkakörülmények-felmérés

Keywords: digitisation, automation/robotisation anxiety, occupation vs. task centred approaches, creative, constrained problem solvers, taylorized workers, European Working Condition Survey

A 2010-es években az európai gazdaság olyan jól ismert problémák mellett, mint az elöregedés, népességcsökkenés, migráció, az újonnan létesített, dinamikus vállalkozások csökkenő száma stb., fokozott mértékben van kitéve a digitalizáció-automatizáció-robotizáció foglalkoztatásra gyakorolt kedvezőtlen hatásainak. A technológiai változások foglalkoztatásra gyakorolt pesszimista előrejelzéseinek, az ún. ,,automatizáció generálta nyugtalanságnak" (anxiety of automation) jelentős tradíciói vannak a közgazdaságtanban és általában a társadalomtudományokban. Korántsem új jelenségek a technológiai változások leegyszerüsített, determinisztikus értelmezései a társadalomtudományokban, legyen szó azok pesszimista vagy optimista változatairól.

Például már a 20. század első harmadában John Maynard Keynes $(1931,358$. előre jelezte a technológiai munkanélküliséget mint a gazdasági fejlődés új betegségét. Mindazonáltal felhívta a figyelmet arra is, hogy a fejlődésben lemaradó országok kedvezőtlenebb helyzetbe kerülnek, és a technológiai változásokat kísérő alkalmazkodási nehézségek átmeneti jellegüek, hosszú távon az emberiség mindig válaszolt ezekre a kihívásokra. Két évtizeddel később Wassily Leontief (1952) pesszimistább nézetet képviselt, amikor arról írt, hogy a jövőben a munka egyre kevésbé lesz fontos, a gépek egyre több munkást fognak tudni helyettesíteni, míg az ötvenes évek elején nem látszódtak azok az új iparágak, amelyek a feleslegessé vált munkaerőt képesek lennének foglalkoztatni.

Mintegy fél évszázadon keresztül a technológiai változásokkal kapcsolatos, tömeges munkanélküliséget elörejelző nézetek nem igazolódtak be. Az új technikák bevezetését kísérő foglalkozatási gondok átmeneti, rövid távú alkalmazkodási nehézségeknek számítottak. Sőt, az olyan radikális technológiai fejlesztések is legendás bukással végződtek, mint ,a jövő automatizált gyára” elöhírnökének tekintett autógyári kísérlet, a Volkswagen (VW) „Halle 54” projektje, amely a cég wolfsburgi üzemének végszereldéjében bevezette a számítógép által vezérelt gyártást (Computer Integrated Manufacturing, CIM). Ennek hatására óriásira nőtt a selejtes autók száma, azok javítása ráfizetésessé tette a gyártást. Az 1980-as évek végére a termelés teljes automatizálására irányuló törekvések megszakadtak, az emberi tényező teljes kiiktatását célzó megoldások mind megbuktak. Részben Lothar Hackot és Sabine Pfeiffert is idézve, Ralf Kopp és munkatársai a VW sikertelen automatizációs törekvését úgy minősítették, mint a racionalizáció és modernizáció szük látókörü technológiai megközelítésének dinoszauruszát, amelyben még magát a munkaszervezetet is technológiaként interpretálták. Sze- 
rintük ez a megközelítés ugyanúgy elérte a határait, mint annak idején a taylorizmus. Mindkét kísérlet bukásának alapvető oka, hogy racionalizációs stratégiájuk az emberközpontú munkaszervezés radikális megkérdőjelezésén alapult (Hack, 1994; Pfeiffer, 2010; mindkettőt idézi Kopp et al., 2016).

A századfordulót követően viszont a digitalizáció (intelligens robotok, vezető nélküli autók, 3D-nyomtatás stb.) beköszöntével ismét tanúi lehetünk a technológiai munkanélküliséget, vagy általánosabban megfogalmazva, az ún. automatizációs nyugtalanságot (automation anxiety) képviselő nézetek feltámadásának (Ford, 2015; Brynjolfsson-McAfee, 2014.). Mindazonáltal, a korábbi nézetekkel szemben, a digitalizáció változatos formáival foglalkozó szakemberek hangsúlyozzák, hogy a robotok napjainkban és főleg a jövőben az embernek nem ellenségei, hanem együttmüködő partnerei lesznek.

Az automatizáció fejlettebb formáinak (például az emberek közötti mindennapi kommunikáció felismerésére képes számítógépek) térnyerésével, a következő évtizedekben a technológiai változások foglalkoztatásra gyakorolt hatásairól meglehetősen eltérő becslések jelennek meg. Szalavetz Andrea (tanulmányát lásd e szám 55-60. oldalán) valóságos „számháborúhoz” hasonlítja az előbb említett technológiai változások foglalkoztatásra gyakorolt hatásairól szóló becsléseket. Az USA-ban például, Carl Benedikt Frey és Michael Osborne (2015) szerint, az alkalmazottak mintegy felének (47\%) a munkáját számítógépek és algoritmusok helyettesítik a következő egy-két évtizedben. Jeremy Bowles (2014) szerint az európai munkahelyek 45-60\%-át fogják automatizálni. Európán belül, a szakemberek szerint, a német gazdaságban minden második munkahelyet (57\%) fenyeget az automatizáció kockázata (Brezski-Burk, 2015).

A legújabb elemzések az automatizáció és a robotizáció foglalkoztatásra gyakorolt hatásairól az említetteknél differenciáltabb következményekre hívják fel a figyelmet, és elvetik a radikális változásokat képviselő, leegyszerüsítő forgatókönyveket. Például, a nemzetközileg elismert tanácsadó cég, a McKinsey \& Company egyik legújabb kutatása, amelyben mintegy nyolcszáz foglalkozás kétezernél is több tevékenységét elemezték részletesen az USA-ban, arra figyelmeztet, hogy a következő évtizedben az automatizáció csak nagyon kevés foglalkozás teljes eltűnését fogja eredményezni. Ehelyett olyan átfogó átalakulásról van szó, amely kisebb vagy nagyobb mértékben a munkafeladat tartalmától függően minden foglalkozást érinthet (Chui et al., 2016, 1.). Az OECD huszonegy országára vonatkozó legújabb elemzése (Arntz et al., 2016) a fenti kutatáshoz nagyon hasonló következtetésekre jutott. Frey és Osborne (2015) 47\%-os becslésével szemben szerintük az amerikai foglalkozásoknak alig egytizede (9\%) van kitéve a megszünés kockázatának.

Az utóbb említett vizsgálatok tapasztalatai szerint az automatizáció foglalkoztatásra gyakorolt következményeinek jelentős különbségei a kutatások elméleti-módszertani alapjainak különbségeivel magyarázhatók. Az automatizáció fog- 
lalkoztatásra gyakorolt hatásait túlértékelő elemzések a technológiai változások egész foglalkozásokra, nem pedig az azok tartalmát jelentő munkafeladatokra gyakorolt hatásaira koncentrálnak. Ezzel szemben a kevésbé radikális, de átfogóbb változásokat prognosztizáló elemzések az automatizáció/robotizáció munkafeladatokra gyakorolt hatásainak azonosításával és értékelésével foglalkoznak. Eszerint a technológiai változások a munkafeladatoknak csak egy részét, és nem egész foglalkozásokat tesznek feleslegessé, ily módon pedig elvetik a „munka nélküli jövő" (jobless future) társadalomképét. Melanie Arntz és munkatársai eredményei ezzel együtt abban hasonlítanak Keynes már idézett munkájára, hogy ők is jelentős különbségeket mutattak ki az egyes országok között. Becslésük szerint Koreában például csak $6 \%$ az automatizáció által érintett állások aránya, míg Ausztriában ugyanez az arány ennek éppen a duplája, vagyis $12 \%$. E különbségeknek számos oka van, kezdve a munkaszervezésben megmutatkozó differenciáktól, az automatizációs technológiák fejlesztésére fordított korábbi befektetések mértékén át, egészen az oktatási rendszerben meglévő sajátosságokig (Arntz et al., 2016, 25.).

Egy megjelenés előtt álló tanulmányunkban mi is megkíséreltük elemezni a várható trendeket (Makó et al., 2018). Ennek során az európai munkakörülményekről szóló felmérés (European Working Conditions Survey) adatait elemeztük. A változók két csoportját vizsgáltuk, az egyik a munkafeladatok kreatív, kognitív dimenzióját mérte, a másik az azok ellátása során élvezett munkavállalói autonómia mértékét. Az automatizáció szempontjából két kulcsfontosságú tényezőről van szó, hiszen nyilvánvaló, hogy sem azok a munkafeladatok nem alkalmasak automatizációra, amelyek komplex kognitív képességeket igényelnek, sem pedig azok, amelyek elvégzése során a munkavállalók nagyfokú autonómiát élveznek. A klaszterelemzés végén a munkavállalók három nagyobb csoportja volt elkülöníthető: a kreatív dolgozók csoportjába azok a munkavállalók kerültek, akiknek a kognitív képességeiket nagymértékben kell mozgósítaniuk a munkavégzés során, illetve nagyfokú autonómiát élveznek. A taylori elvek alapján szerveződő állások képviselték a skála másik végét, a kognitív képességek igénybevétele és az autonómia ezekre az állásokra volt a legkevésbé jellemző. A kettő között, de a kreatív munkavállalókhoz közelebb található az úgynevezett ellenőrzött problémamegoldó (constrained problem solvers) munkavállalók csoportja, akik kreatív munkát végeznek, de jelentősen kevesebb autonómiát élveznek mindeközben.

Az adatok 2005-ből, 2010-ből és 2015-ből származnak, tehát alkalmasak arra, hogy a digitalizáció mellett a válság hatását is jelezzék. Az eredmények részletes bemutatására jelen cikk keretei között nincs lehetőségünk. Magyarország vonatkozásában azonban mindenképpen fel kell hívnunk a figyelmet arra a roppant kedvezőtlen tendenciára, amely szerint 2005 és 2015 között a kreatív munkavállalók aránya jelentősen csökkent (44\% vs. 37\%), míg a taylori munkavállalók aránya ugyanilyen jelentős arányban nőtt ( $27 \%$ vs. $33 \%)$. 
KONKLÚZIÓ

Természetesen, a digitalizáció munkavégzésre gyakorolt országonkénti jelentős különbségeiben nemcsak foglalkozás- versus munkafeladat-centrikus megközelítések eredményeznek jelentős differenciákat. A munkafeladatok - és ezen keresztül a foglalkozások - automatizáció általi kiváltásában nem lehet egyetlen tényező, például a technológiai lehetőségek szerepét kiemelni, ehelyett abban számos, egymással kölcsönhatásban érvényesülő tényező szerepét ajánlatos vizsgálni. Például már a McKinsey kutatási jelentés (Chui et al., 2016) is hangsúlyozza az olyan makrogazdasági és társadalmi szabályozók szerepét, mint az automatizáció morális-jogi elfogadottsága, szabályozása, a munkaerőpiaci kereslet-kínálat viszonya. Nyilvánvaló például, hogy egészen más lesz az automatizáció hatása abban az országban, ahol a robotok után is kell majd társadalombiztosítási járulékot fizetni, mint ahol nem. A tanulmányunkban idézett OECD-országok példáját használó elemzés (Arntz et al., 2016, 23-24.) a technológiai változások munkaerő-helyettesítést ellensúlyozó következő három közvetett hatását emeli ki:

1. A munkaerő kiváltását lehetővé tévő technológiák más szektorokban és más képzettségi szintet követelő foglalkozásokban növelik a munkaerő iránti keresletet.

2. Miután az új technológiák jellemzően magasabb termelékenységet tesznek lehetővé, ezzel növelik a vállalatok versenyképességét. Az árak és költségek csökkenésével viszont növelhetik a megtermelt áruk és szolgáltatások iránti keresletet, ezzel pedig akár a munkaerö-keresletet is növelhetik.

3. A termelékenység növekedésével vagy a foglalkoztatás, vagy a munkabérek nőhetnek, optimális esetben mindkettő. Ha pedig nő a háztartások által elkölthető jövedelem, az tovább növelheti az áruk és szolgáltatások iránti keresletet, ami szintén kedvezően hat a munkaerő-keresletre.

Az biztos, hogy az automatizáció hatásainak vizsgálata nem új jelenség a társadalomtudományi szakirodalomban, inkább egyidős vele. Jelentős különbségek vannak a jelenleg elérhető prognózisokban aszerint, hogy az elemzők foglalkozások bizonyos kategóriáját vizsgálják, vagy a munkafeladatok konkrét tartalmára koncentrálnak. Az elöbbi megközelítés szerint a technológiai változások radikális mértékben csökkenthetik a foglalkoztatás szintjét. Mi az utóbbi, a munkafeladatok tartalmára koncentráló elemzéseket tartjuk megalapozottabbnak. Ez az irányzat az automatizáció és a robotizáció nem kevésbé radikális hatását jósolja, de a kölcsönhatások irányai jóval összetettebbek, a kérdés nem egyszerüsíthető le pusztán a megszűnő munkahelyek arányára, a foglalkoztatás szintjének csökkentésére. Bizonyos foglalkozásokban, munkakörökben kétségkívül számolhatunk ezzel is, ugyanakkor a gépek és robotok jóval több mun- 
kahely esetén kiegészítő tevékenységet fognak ellátni. Ezekben az esetekben a hatások között számon kell tartanunk a termelékenység növekedését, a munkavégzés feltételeinek (job quality) javulását, nem mellesleg pedig a munkahelymegtartó képesség növekedését.

Ez utóbbi kapcsán különösen aggasztó lehet, hogy a közép- és kelet-európai országokban a válság után jelentősen nőtt a taylori munkavállalók aránya. Feltételezésünk szerint ezek azok az állások, amelyek legkönnyebben kiválthatók gépekkel és robotokkal. Ma még talán olcsóbb ezeket a tevékenységeket e régió alacsony munkaerőköltségủ országaiban végeztetni, de reális forgatókönyv, hogy a technológiai fejlődéssel visszaviszik őket az anyaországba, ahol számítógépek vagy robotok végzik majd el ezt a munkát a kelet-európai munkavállalók helyett. Magyarország ebböl a szempontból kiemelten veszélyeztetett helyzetben van.

További nagy kérdés, hogy az okos technológiák fejlődése és térnyerése hogyan alakítja át a közszolgáltatások természetét, egyrészt a fogyasztók, másrészt az ott dolgozók szempontjából. Ez a terület általában kimarad az automatizáció foglalkoztatási hatásait felmérni igyekvő tanulmányokból, melyek leginkább a gépgyártásra vagy tágabban, az iparra korlátozódnak. A legfrissebb kutatási eredmények azonban arra hívják fel a figyelmet, hogy amilyen mélyreható változásokat eredményezhet az Ipar 4.0 a termelö szektorok mindennapjaiban, ugyanilyen alapvető változásokat okozhat a közszolgáltatások harmadik generációjának megjelenése (Laitinen-Stenvall, 2016, 4-5.). E harmadik generációs szolgáltatások közös jellemzője, hogy a szolgáltatások tervezésének, szervezésének és ellátásának középpontjában a szolgáltatást nyújtó szervezet helyett a fogyasztó áll, akit már a tervezés folyamatába igyekeznek bevonni. Mindezt jelentős mértékben az új technológiák teszik lehetővé, amelyek biztosítják, hogy a szolgáltatást nyújtó szervezetben dolgozók folyamatosan új információkat szerezzenek a fogyasztók igényeiről, ezzel biztosítva a folyamatos tanulást egyéni és szervezeti szinten egyaránt. Ezek a kutatások ugyan egyelöre szintén gyerekcipőben járnak, de valószínüsíthető, hogy az okos technológiák térnyerése ebben a szektorban is komplexebb átalakulást indukál majd, mint a munkahelyek bizonyos számának megszünése.

\section{IRODALOM}

Acemoglu, D. - Restrepo, P. (2017): Robots and Jobs: Evidence from US Labour Markets. Working Paper 23285, National Bureau of Economic Research, Cambridge, MA 02138, http://www.nber. org/papers/w23285

Arntz, M. - Gregory, T. - Zierahn, U. (2016): The Risk of Automation for Jobs in OECD Countries. OECD Social, Employment and Migration Working Papers, No. 189, 34. http://www.oecd-il- 
ibrary.org/social-issues-migration-health/the-risk-of-automation-for-jobs-in-oecd-countries

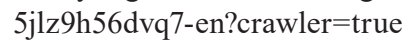

Bowles, J. (2014): The Computerization of European Job. Brussels: Bruegel. http://bruegel. org/2014/07/the-computerisation-of-european-jobs/

Brezski, C. - Burk, I. (2015): The Robots Come. Consequences of Automation for the German Labour Market, ING DiBa Economic Research. In: Arntz, M. - Gregory, T. - Zierahn, U. (2016): The Risk of Automation for Jobs in OECD Countries. OECD Social, Employment and Migration Working Papers, No. 189, 7. http://www.oecd-ilibrary.org/social-issues-migration-health/ the-risk-of-automation-for-jobs-in-oecd-countries_5jlz9h56dvq7-en?crawler=true

Brynjolfsson, E. - McAfee, A. (2014): The Second Machine Age: Work, Progress, and Prosperity in a Time of Brilliant Technologies. New York-London: W.W. Norton \& Company. https:// edisciplinas.usp.br/pluginfile.php/622156/mod_resource/content/1/Erik-Brynjolfsson-Andrew-McAfee-Jeff-Cummings-The-Second-Machine-Age.pdf

Chui, M. - Manyika, J. - Miremadi, M. (2016): Where Machines Could Replace Human-and Where They Can't (Yet), (The Technical potential for automation differs dramatically across sectors and activities). McKinsey Quarterly, July, 13. https://www.mckinsey.com/business-functions/digital-mckinsey/our-insights/where-machines-could-replace-humans-andwhere-they-cant-yet

Ford, M. (2015): The Rise of the Robots. New York: Basic Books

Frey, C. B. - Osborne, M. A. (2015): Technology at Work: The Future of Employment: How Susceptible are Jobs to Computerization? Citi GPS: Global Perspectives \& Solutions, February, http://www.oxfordmartin.ox.ac.uk/downloads/reports/Citi_GPS_Technology_Work. pdf

Hack, L. (1994): Industriesoziologie. In: Kerber, H. - Schmieder, A. (Hrsg.): Spezielle Soziologien. Problemfelder, Forschungsbereiche, Anwendungsorientierungen. Hamburg: Reinbeck Rowohlt, 40-74.

Keynes, J. M. (1930): Essays in Persuasion. (Ch. V Future, Section 2: Economic Possibilities for our Grandchildren, 1930). London: MacMillan and Co. Ltd. https://gutenberg.ca/ebooks/keynes-essaysinpersuasion/keynes-essaysinpersuasion-00-h.html

Kopp, R. - Howaldt, J. - Schultze, J. (2016): Why Industry 4.0 Needs Workplace Innovation: A Critical Look at the German Debate on Advanced Manufacturing. European Journal of Workplace Innovation, 2, 1, 7-24. http://journal.uia.no/index.php/EJWI/article/download $/ 373 / 315$

Laitinen, I. - Stenvall, J. (2016): Entering the Era of Third Generation Services: A Comparative Study of Reforms in Social and Health Care Services. Journal of Adult and Continuing Education, 22, 1. DOI: 10.1177/1477971416628725 http://journals.sagepub.com/doi/ pdf/10.1177/1477971416628725

Leontief, W. (1952): Machines and Man. Scientific American, 187, 3, 150-160. DOI: 10.1038/scientificamerican0952-150

Lorenz, E. - Lundvall, B. - A. (2010): Accounting for Creativity in the European Union: A Multi-level Analysis of Individual Competence, Labour Market Structure, and Systems of Education and Training. Cambridge Journal of Economics. Advance Access: April, 26. Published: 1 March 2011, 35, 2, 269-294. DOI: 10.1093/cje/beq014

Makó Cs. - Illéssy M. - Borbély A. (2018): Creative Workers in Europe: Is It a Researve of the 'Would Be Entrepreneurs?' (A Cross Country Comparison). In: Dallago, Bruno - Tortia, Ermanno (eds.): Entrepreneurship and Regional Economic Development: A Comparative Perspective on Entrepreneurs, Universities and Governments. Routledge-Taylor and Francis Group (közlésre elfogadva) 
Pfeiffer, S. (2010): Technisierung von Arbeit. In: Böhle, F. - Voß, G. - Wachtler, G. (Hrsg.): Handbuch Arbeitssoziologie. Wiesbaden, Springer-Verlag, 231-262.

Richta, R. (1967): The Scientific and Technological Revolution. Australian Left Review, June-July, 54-67. http://ro.uow.edu.au/alr/vol1/iss7/11/

Sirkin, H. L. - Zinser, M. - Rose, J. R. (2015): The Robot Revolution. The Next Great Leap in Manufacturing. Boston Consulting Group, https:/circabc.europa.eu/sd/a/b3067f4e-ea5e-48649693-0645e5cbc053/BCG_The_Robotics_Revolution_Sep_2015_tcm80-197133.pdf

Szalavetz A. (2018): Ipari fejlődés és munka a tudásalapú társadalomban. Magyar Tudomány, 179, 1, 55-60. (jelen lapszám) 